\title{
Influence of agro-ecological production areas on antioxidant activity, reducing sugar content, and selected phytonutrients of orange-fleshed sweet potato cultivars
}

\author{
Nozipho Mgcibelo MOTSA ${ }^{1 \star}$, Albert Thembinkosi MODI ${ }^{1}$, Tafadzwanashe MABHAUDHI ${ }^{1}$
}

\begin{abstract}
Sweet potato is an important staple, and it is mainly known for its contribution of $\beta$-carotene in human diet. The effects of cultivar and habitat on this pigment and other nutritional characteristics of the crop still require investigation. In this study, three locally bred cultivars of sweet potato, two of which are orange-fleshed, were grown in three different agro-ecological areas to determine soluble sugar content, $\beta$-carotene, and total antioxidants of roots. In addition antioxidant activity, total carotenoids, and chlorophyll content were determined in edible leaves. Reducing sugars, $\beta$-carotene, total antioxidants capacity, total carotenoids, and chlorophyll content were significantly affected by environmental conditions. The location at lower altitude and closer to the coastline showed high evapotranspiration, thus reducing sugar content, antioxidant activity, and phytonutrients in both storage roots and leaves. Absence of water stress in agro-ecological locations further inland and at higher altitudes was associated with an increase in these compounds. Free radical scavenging activity of DPPH was higher in the storage roots $(610.49 \mu$ moles TE/100g) than in the leaves $(426.06 \mu$ moles TE/100g); nevertheless, opposite results were found for the ferric ion reducing activity (FRAP). The deep orange-fleshed cultivar A 45 contained high $\beta$-carotene $(15 \mathrm{mg} / 100 \mathrm{~g})$, which is enough to meet RDA for vitamin A. There is evidence of agro-ecological effect on sweet potato nutritional value.
\end{abstract}

Keywords: agro-ecological areas; sweet potato cultivars; reducing sugars; phytonutrients.

Practical Application: sweet potato sugar and phytonutrient content can be adversely affected by drought stress. Sweet potato leaves should be promoted in diets of food insecure communities due to their high phytonutrients contents and antioxidant capacity which have potential to contribute to human health and nutrition.

\section{Introduction}

Sweet potato (Ipomoa batatas L.) is one of the most important albeit underutilised (Ali et al., 2012) crops and source of essential nutrients, primarily vitamin A (in the orange-fleshed varieties) (Kulembeka et al., 2004; Agili et al., 2012; Laurie \& Van Heerden, 2012). Consumers are increasingly conscious about their health and have since started to consider the nutritional benefits, disease prevention, and health-promoting properties of foods. This consumers' consciousness calls for critical evaluation of the nutritional composition and health-promoting potential of food crops in order to satisfy their needs. Sweet potato has a great potential role in this respect (Ahmad et al., 2011; Van Jaarsveld et al., 2005).

Information on other beneficial compounds found in sweet potato roots besides the already known nutrients (starch content, mineral content, and $\beta$-carotene content) is envisaged to further increase appreciation and consumption of the crop. Human consumption of the other plant parts such as the leaves can also improve its nutritional value. A recent study by Laurie \& Van Heerden (2012) reported good acceptability of beta-carotene-rich sweet potato leaves as a leafy vegetable, which indicated the need to promote consumption of leaves. According to Islam (2006), sweet potato leaves have largely been neglected except for partial use as livestock feed. The leaves are reported to hold high nutrient composition and higher concentrations of polyphenols compared with major commercial vegetables such as spinach, broccoli, cabbage, and lettuce (Islam, 2006). Whether these concentrations (polyphenols and nutrients) increase or decrease in response to differences in growth environmental conditions, is still not clear.

The taste and gustatory perception of a food crop plays a vital role in increasing chances of its acceptance and utilization. Laurie \& Magoro (2008) and Kulembeka et al. (2004) reported that taste of sweet potato storage roots was an important characteristic that influenced acceptability of new varieties. Soluble sugars have been reported to be affected by variations in growth environments (Wolf et al., 1991), apart from genotype. While this is true, there is limited empirical information reporting on other chemical responses of sweet potato to differences in agro-ecological areas in Southern Africa.

The objective of the study was to determine the effect of production agro-ecological areas on sugar content, $\beta$-carotene, and total antioxidants capacity of storage roots from three sweet potato cultivars. Total antioxidants activity, carotenoids, and chlorophyll content were further determined in young leaves, which are suitable for use as leafy vegetables, from these three sweet potato cultivars, 


\section{Materials and methods}

\subsection{Plant material and agroecological areas}

Three sweet potato cultivars (A40, A45, and 199062.1) were obtained from the University of KwaZulu-Natal's plant breeding programme. Sweet potato cultivar A40 is a cream-fleshed variety, while the other two are orange-fleshed. All three sweet potato cultivars were derived from field trials planted on the first week of November 2012 in three different agro-ecological locations (Deepdale, Umbumbulu, and Richards Bay) (Table 1). Planting was done on ridges $(\sim 30 \mathrm{~cm}$ high) in a randomized complete block design with three replications per location. In all locations, sweet potatoes were planted on land that had been fallow for at-least a year (Table 1). Soil samples were taken prior to planting and analysed for fertility and textural characteristics (Table 1). No fertilizer, pesticides, or supplementary irrigation were applied during crop growth at all experimental sites. Details of weather parameters (maximum and minimum temperatures, reference evapotranspiration, and rainfall) were obtained from the Agricultural Research Council - Institute for Soil, Climate, and Water's network of automatic weather stations. Agronomic conditions and crop management were kept identical in all locations throughout the growth period. Harvesting was conducted at 120 days after planting, where marketable storage roots (100-500 g) and young leaf material (up to the fourth youngest leaf) suitable for cooking were selected for chemical evaluation.

\subsection{Chemical analysis}

Free radical scavenging assay

Extraction was carried out using perchloric acid; $0.2 \mathrm{~g}$ of freeze-dried and ground plant material, (leaves and storage roots) was mixed with $10 \mathrm{ml}$ of perchloric acid and allowed to stand for 10 minutes. The mixture was vortexed for 1 minute before being centrifuged at $12400 \times \mathrm{g}$ at $4^{\circ} \mathrm{C}$ for 10 minutes. Extracts were performed in triplicate. The 2,2 -diphenyl-1-picrylhydeazil (DPPH) free radical scavenging activity of each sample was determined according to Wong et al. (2006). The antioxidant capacity based on the DPPH free radical scavenging ability of the extract was expressed as $\mu \mathrm{mol}$ Trolox equivalents per gram of plant material on a dry matter basis.

\section{Ferric reducing ability of plasma assay}

Extraction was performed as described for the DPPH free radical scavenging assay. The ability to reduce ferric ions was measured using the method described by Wong et al. (2006). The antioxidant capacity based on the ability to reduce ferric ions of the extract was expressed as $\mu$ mol Trolox equivalents per gram of plant material on a dry matter basis.

\section{Carotenoids and chlorophyll concentration}

Carotenoids and chlorophyll were extracted (in triplicate) and determined according to Lichtenthaler (1987) in freeze-dried, ground sweet potato leaf material (0.2 g DM). Calculations and conversions were made using the Equations 1 to 4 :

$$
\begin{aligned}
& \mathrm{C}_{\mathrm{a}}=\left(12.25 \times \mathrm{A}_{663.2}\right)-\left(2.79 \times \mathrm{A}_{646.8}\right) \\
& \mathrm{C}_{\mathrm{b}}=\left(21.50 \times \mathrm{A}_{646.8}\right)-\left(5.10 \times \mathrm{A}_{663.2}\right) \\
& \mathrm{Ca}+\mathrm{b}=\left(7.15 \times \mathrm{A}_{663.2}\right)-\left(8.71 \times \mathrm{A}_{646.8}\right) \\
& \mathrm{C}_{\mathrm{x}+\mathrm{c}}=\left(1000 \times \mathrm{A}_{470}\right)-\left(1.82 \times \mathrm{C}_{\mathrm{a}}\right)-\left(85.02 \times \mathrm{C}_{\mathrm{b}}\right) / 19
\end{aligned}
$$

\begin{tabular}{|c|c|c|c|}
\hline & Deepdale & Richards Bay & Umbumbulu \\
\hline $\begin{array}{l}\text { Agroecological zone } \\
\text { (Bio-resource group) }\end{array}$ & Coast hinterland thornveld & $\begin{array}{l}\text { Moist coast forest, thorn and } \\
\text { palm-veld }\end{array}$ & $\begin{array}{l}\text { Moist coast hinterland and } \\
\text { ngongoni veld }\end{array}$ \\
\hline Geographical location & $28^{\circ} 01^{\prime} \mathrm{S} ; 28^{\circ} 99^{\prime} \mathrm{E}$ & $28^{\circ} 19^{\prime} \mathrm{S} ; 32^{\circ} 06 \mathrm{E}$ & $29^{\circ} 98^{\prime} \mathrm{S} ; 30^{\circ} 70^{\prime} \mathrm{E}$ \\
\hline Altitude (m a.s.l.)z & 998 & 30 & 632 \\
\hline Annual rainfall & $7500-850 \mathrm{~mm}$ & $820-1423 \mathrm{~mm}$ & $800-1160 \mathrm{~mm}$ \\
\hline Average temperature & $18.4^{\circ} \mathrm{C}$ & $22^{\circ} \mathrm{C}$ & $17.9^{\circ} \mathrm{C}$ \\
\hline Frost occurrence & moderate & None & Light and occasional \\
\hline${ }^{*}$ Soil texture class & clay & Sand & Clay \\
\hline Clay content & $53 \%$ & $<5 \%$ & $>60 \%$ \\
\hline Soil pH & 4.4 & 3.6 & 4.2 \\
\hline *Soil type & Jonkersberg form (Jb) & Inhoek form (Ik) & Hutton form $(\mathrm{Hu})$ \\
\hline Soil depth & $1.0 \mathrm{~m}$ & $>1.0 \mathrm{~m}$ & $1.0 \mathrm{~m}$ \\
\hline Nitrogen $(\%)$ & 0.4 & 0.1 & 0.3 \\
\hline Phosphorus (mg/L) & 5.0 & 6.0 & 1.0 \\
\hline Potassium (mg/L) & 349.0 & 18.0 & 62.0 \\
\hline Organic carbon (\%) & 4.4 & $<0.5$ & 3.4 \\
\hline Previous crop & Fallow ( 3 years) & Fallow (1 year) & Fallow (1 year) \\
\hline Total rainfall received $(\mathrm{mm})$ & 466.9 & 563.2 & 557.4 \\
\hline Total ETo $(\mathrm{mm})$ & 17.2 & 567.2 & 449.2 \\
\hline
\end{tabular}

Table1. Experimental site description for Deepdale (Agro-ecological group 17), Richards Bay (Agro-ecological group 1), and Umbumbulu (Agro-ecological group 3).

${ }^{\star}$ Soil Classification, a Taxonomic System for South Africa $1991 ;{ }^{2}$ metres above sea level. 
Where: $\mathrm{C}_{\mathrm{a}}=$ Chlorophyll $\mathrm{a}$,

$\mathrm{C}_{\mathrm{b}}=$ Chlorophyll b,

$\mathrm{C}_{\mathrm{a}+\mathrm{b}}=$ Total Chlorophyll, and

$\mathrm{C}_{\mathrm{x}+\mathrm{c}}=$ Total carotenoids.

\section{Pigment extraction for $\beta$-carotene analysis}

The sampling of sweet potato roots for $\beta$-carotene was done as described by Rodriguez-Amaya \& Kimura (2004). Extraction was then carried out in triplicate, according to the method of the Association of Official Analytical Chemists (Howitz, 1980) using a $5 \mathrm{~g}$ sample of macerated sweet potato storage root (with $1 \mathrm{mg}$ of BHT).

The concentration of $\beta$-carotene was calculated using Beer-Lamberts Law, which states that absorbance $(A)$ is proportional to the concentration $(\mathrm{C})$ of the pigment, as represented by the Equation 5:

A $\infty \mathrm{L}$ (if concentration $(\mathrm{C})$ is constant).

$\mathrm{A}=\mathrm{ECL} ; \mathrm{C}=\mathrm{A} / \mathrm{EL}$

Where: $\mathrm{C}=$ concentration of carotene,

$\mathrm{A}=$ absorbance,

$\mathrm{E}=$ extinction coefficient,

$\mathrm{L}=$ thickness of cuvettes (path length) $=1 \mathrm{~cm}$, and

$\mathrm{E}$ of $\beta$-carotene $=1.34 \times 10^{5} \mathrm{l} / \mathrm{mol} \mathrm{cm}(\mathrm{M}=537 \mathrm{~g} / \mathrm{mol})$.

\section{Extraction of soluble sugars}

Soluble sugars were extracted and determined according to Liu et al. (1999) using freeze-dried, ground material (0.10 g DM) mixed with $10 \mathrm{ml} 80 \%(\mathrm{v} / \mathrm{v})$ ethanol and homogenized for 60 seconds. The concentration of individual sugars was determined by comparison with authentic sugar standards.

\subsection{Statistical analyses}

Data were subjected to analysis of variance (ANOVA) using GenStat version 14 (VSN International, Hemel Hempstead, UK). Tukey's test was used to separate means at the $5 \%$ level of significance.

\section{Results}

\subsection{Antioxidant activity}

Results of the two antioxidant activity assays (FRAP and $\mathrm{DPPH})$ showed significant differences $(\mathrm{P}<0.05)$ among the agro-ecological locations and sweet potato cultivars (Table 2). The interaction between location and sweet potato cultivar was also significant $(\mathrm{P}<0.001)$ (Tables 2 and 3$)$. The reducing power (measured using the FRAP assay) of storage roots harvested at Richards Bay was higher than those harvested from Umbumbulu and Deepdale, respectively (Table 2). The DPPH free radical scavenging activity, on the other hand, was higher for storage root extracts harvested at Deepdale followed by Richards Bay and the lowest for Umbumbulu root extracts. Sweet potato leaf extracts followed a similar trend when subjected to DPPH free radical scavenging essay (Table 3 ). The reducing power of leaf extracts was higher for Umbumbulu sweet potato leaves, while Deepdale sweet potato leaves had very low reducing activity.

The antioxidant activity of the sweet potato cultivars A40 and A45 varied within the assays used. Cultivar A40 had relatively higher reducing power, whereas cultivar A45 had relatively higher radical scavenging activity. This trend was observed in both the leaf and storage root extracts. It was also observed that the ferric ion reducing activity values of the leaves were consistently higher than the DPPH free radical scavenging values. Sweet potato cultivar 199062.1 seemed more stable as far as the antioxidant activities were concerned. Significant negative correlation $(\mathrm{r}=0.81 ; \mathrm{p}<0.05)$ was also found between the two antioxidant activity assays when applied on the leaves.

Table 2. Total antioxidant activity in storage roots of three sweet potato cultivars harvested from different locations.

\begin{tabular}{|c|c|c|c|c|c|c|}
\hline \multirow{2}{*}{$\begin{array}{c}\text { SweetPotato } \\
\text { cultivars }\end{array}$} & \multicolumn{3}{|c|}{ DPPH $(\mu$ moles TE/100g) } & \multicolumn{3}{|c|}{ FRAP $(\mu$ moles TE/100g) } \\
\hline & Deepdale & Umbumbulu & Richards Bay & Deepdale & Umbumbulu & Richards Bay \\
\hline A40 & $631.9 \pm 0.18^{\mathrm{b}}$ & $559.8 \pm 0.62^{c}$ & $587.0 \pm 0.05^{c}$ & $178.2 \pm 0.10^{\mathrm{b}}$ & $355.2 \pm 0.78^{\mathrm{b}}$ & $622.0 \pm 1.61^{\mathrm{a}}$ \\
\hline A45 & $632.5 \pm 0.23^{\mathrm{a}}$ & $616.3 \pm 0.43^{\mathrm{a}}$ & $619.0 \pm 0.26^{\mathrm{b}}$ & $178.1 \pm 0.39^{\mathrm{b}}$ & $263.4 \pm 0.88^{c}$ & $254.3 \pm 3.90^{\mathrm{b}}$ \\
\hline 199062.1 & $629.8 \pm 0.38^{c}$ & $596.7 \pm 0.08^{\mathrm{b}}$ & $621.5 \pm 0.19^{\mathrm{a}}$ & $256.8 \pm 0.28^{\mathrm{a}}$ & $437.9 \pm 0.25^{\mathrm{a}}$ & $305.0 \pm 0.26^{c}$ \\
\hline
\end{tabular}

Means in each column with different letters are significantly different $(\mathrm{P}<0.05)$; TE $=$ Trolox equivalent.

Table 3. Total antioxidant activity in the leaves of three sweet potato cultivars harvested from different locations.

\begin{tabular}{|c|c|c|c|c|c|c|}
\hline \multirow{2}{*}{$\begin{array}{c}\text { Sweet Potato } \\
\text { cultivars }\end{array}$} & \multicolumn{3}{|c|}{$\mathrm{DPPH}(\mu$ moles TE/100g) } & \multicolumn{3}{|c|}{ FRAP $(\mu$ moles TE/100g) } \\
\hline & Deepdale & Umbumbulu & Richards Bay & Deepdale & Umbumbulu & Richards Bay \\
\hline $\mathrm{A} 40$ & $647.8 \pm 0.25^{c}$ & $268.5 \pm 1.04^{c}$ & $164.3 \pm 3.93^{c}$ & $214.1 \pm 0.1^{\mathrm{b}}$ & $1883.0 \pm 0.78^{\mathrm{b}}$ & $823.8 \pm 1.61^{\mathrm{a}}$ \\
\hline $\mathrm{A} 45$ & $620.7 \pm 0.12^{\mathrm{a}}$ & $309.5 \pm 1.22^{\mathrm{a}}$ & $484.4 \pm 0.07^{\mathrm{a}}$ & $473.0 \pm 0.39^{\mathrm{b}}$ & $1417.2 \pm 0.88^{c}$ & $802.1 \pm 3.90^{\mathrm{b}}$ \\
\hline 199062.1 & $590.2 \pm 0.23^{\mathrm{b}}$ & $305.6 \pm 1.47^{\mathrm{b}}$ & $443.7 \pm 0.23^{\mathrm{b}}$ & $836.1 \pm 0.28^{\mathrm{a}}$ & $1263.2 \pm 0.25^{\mathrm{a}}$ & $1176.1 \pm 0.26^{c}$ \\
\hline
\end{tabular}

Means in each column with different letters are significantly different $(\mathrm{P}<0.05)$; TE $=$ Trolox equivalent. 


\subsection{Carotenoids, $\beta$-carotene and chlorophyll}

Carotenoids, $\beta$-carotene, and chlorophyll content showed significant $(\mathrm{P}<0.05)$ differences across locations and sweet potato cultivars. The interaction between location and sweet potato cultivars was also significant (Table 4 ). With respect to differences between locations, storage roots harvested at Deepdale contained significantly $(\mathrm{P}<0.001)$ higher $\beta$-carotene than the storage roots harvested from Umbumbulu and Richards Bay, respectively. It was also observed that $\beta$-carotene content tended to increase as the agro-ecological location got further away from the coast (Table 1). Very low values were recorded from storage roots harvested from the lowland coastal location (Richards Bay), whilst the highest values were recorded in the storage roots harvested from the upper inland location (Deepdale) (Tables 1 and 4).

Based on mean values of sweet potato cultivars across these locations, cultivar A45 recorded significantly $(\mathrm{P}<0.001)$ higher $\beta$-carotene content than that of the cultivars 199062.1 and A40, respectively. The two orange fleshed sweet potato cultivars (A45 and 199062.1) recorded similar amount of $\beta$-carotene content when planted in Richards Bay (Table 4). Sweet potatoes planted in Richards Bay had low concentrations of chlorophyll and total carotenoids, following a similar trend as that of $\beta$-carotene content of storage roots from that location. Higher concentrations of the two types of phytonutrients (chlorophyll and total carotenoids) were recorded at Umbumbulu and Deepdale respectively. There was a positive correlation $\left(r^{2}=0.76 ; p<0.05\right)$ between carotenoids and chlorophyll contents, but there was no relationship between these two phytonutrients in the leaves and $\beta$-carotene in the storage roots. Chlorophyll and total carotenoids contents followed a similar trend as $\beta$-carotene content in the three sweet potato cultivars. Cultivar A45 recorded the highest $(\mathrm{P}<0.001)$ chlorophyll and carotenoids content, followed by cultivars 199062.1 and A40, respectively (Table 4).

\subsection{Reducing sugar content}

Reducing sugar content varied significantly $(\mathrm{P}<0.001)$ across locations and among the sweet potato cultivars (cultivars). The interaction between the two factors also showed significant variations (Figure 1). Storage roots harvested from Deepdale contained significantly $(\mathrm{P}<=0.001)$ higher sugar content, followed by those harvested from Umbumbulu and Richards Bay. Reducing sugar content followed a similar trend as $\beta$-carotene content from these locations. Sweet potato cultivars, A40, and A45 contained more reducing sugars than that of sweet potato cultivar 199062.1.
While sugar content of cultivar A40 was the highest when planted in Deepdale and Umbumbulu, the opposite was true when planted in Richards Bay. It recorded the lowest sugar content value, which was even lower than those recorded from cultivar 199062.1, an inherently low sugar content variety based on the results obtained for the other two locations. Cultivar A45, on the other hand, showed high stability across the three locations.

\section{Discussion}

The agroecological locations where the sweet potato cultivars were grown had a marked influence on the contents of sugars, $\beta$-carotene, total carotenoids, and chlorophyll and antioxidant activity. This is an indication that environmental conditions do affect the chemical composition of sweet potato roots. The coast hinterland thornveld environmental conditions (Smith, 2006), where Deepdale is located, seemed to favour nutritional status of the sweet potato cultivars. Total rainfall received during the growth period was almost similar $(563.2,557.4$ and $466.9 \mathrm{~mm}$ in Richards Bay, Umbumbulu and Deepdale, respectively) in all three locations, except for total evapotranspiration (ET) (567.2, 449.2 and 17.9mm in Richards Bay, Umbumbulu and Deepdale, respectively ). The ET o was very low in Deepdale, and it is assumed that it may have had a positive influence on the chemical concentration of these compounds. Where ET was higher (in Richards Bay), it created a deficit as it exceeded rainfall received. The deficit therefore imposed water stress conditions to the plants; when coupled with high temperatures, they may have had an adverse effect on the sugars and phytochemical content of the plant parts analysed. Water deficit (resulting from

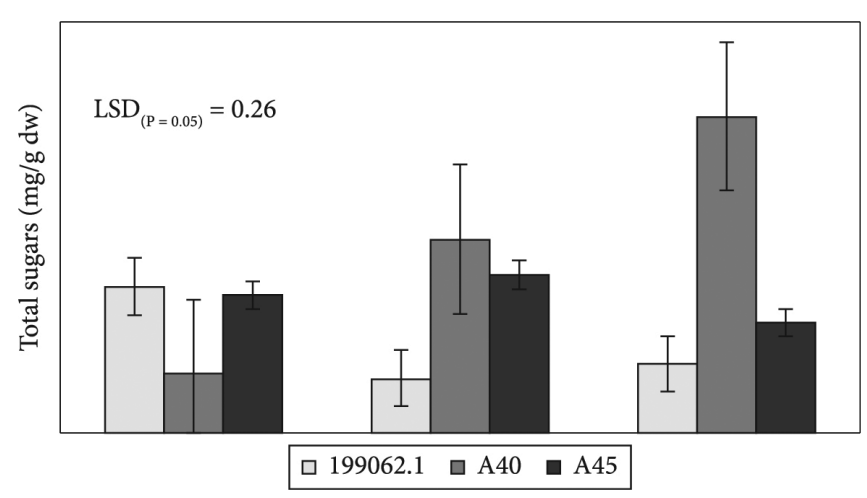

Figure 1. Reducing sugar content of storage roots of three sweet potato cultivars (A40, A45 and 199062.1) harvested from different agroecological locations (R Bay, Umb, Ddale).

Table 4. Phytonutrients of three sweet potato cultivars grown in three different locations ( $\beta$-carotene measured on storage roots, while total carotenoids and chlorophyll content were measured on leaves).

\begin{tabular}{|c|c|c|c|c|c|c|c|c|c|}
\hline \multirow{2}{*}{$\begin{array}{c}\text { Sweet Potato } \\
\text { cultivars }\end{array}$} & \multicolumn{3}{|c|}{$\beta$-carotene $(\mathrm{mg} / 100 \mathrm{~g})$} & \multicolumn{3}{|c|}{ Total carotenoids $(\mathrm{mg} / \mathrm{g})$} & \multicolumn{3}{|c|}{ Chlorophyll $(\mu \mathrm{g} / \mathrm{g})$} \\
\hline & Deepdale & Umb & R. Bay & Deepdale & Umb. & R. Bay & Deepdale & Umb. & R. Bay \\
\hline A40 & $2.9 \pm 0.05^{c}$ & $0.2 \pm 0.05^{\mathrm{c}}$ & $0.98 \pm 0.01^{\mathrm{b}}$ & $0.9 \pm 0.44^{\mathrm{b}}$ & $3.9 \pm 1.97^{\mathrm{a}}$ & $2.6 \pm 1.29^{\mathrm{a}}$ & $3.8 \pm 0.01^{\mathrm{c}}$ & $33.1 \pm 0.02^{\mathrm{a}}$ & $18.9 \pm 0.01^{\mathrm{a}}$ \\
\hline A45 & $23.2 \pm 0.02^{\mathrm{a}}$ & $19.7 \pm 0.05^{\mathrm{a}}$ & $2.3 \pm 0.03^{\mathrm{a}}$ & $3.9 \pm 1.96^{\mathrm{a}}$ & $3.0 \pm 1.97^{\mathrm{a}}$ & $2.3 \pm 1.13^{\mathrm{a}}$ & $44.7 \pm 0.06^{\mathrm{a}}$ & $23.9 \pm 0.01^{\mathrm{c}}$ & $15.4 \pm 0.00^{c}$ \\
\hline
\end{tabular}

$\mathrm{Umb}=$ Umbumbulu; R. Bay = Richards Bay; Means in each column with different letters are significantly different $(\mathrm{P}<0.05)$. 
high ET ) was the dominant variable among these locations. Deepdale is located in an agroecological area which experiences frequent mist during summer season, and this contributed to soil moisture conservation by reducing ET (Food and Agriculture Organization of the United Nations, 1989; Smith, 2006). This is probably why total $\mathrm{ET}_{\mathrm{o}}$ was only $3 \%$ of the value recorded in Richards Bay (Table 1).

Secondary metabolites, such as phenolic antioxidants, are generally known to increase under drought stress conditions, and this is believed to be a response to an increase in oxidative damage (Podsędek, 2007; Oh et al., 2009). Plants grown in Deepdale did not experience any drought stress, yet they recorded high concentrations of total carotenoids, $\beta$-carotene, and antioxidant activity. Carotenoids, on the other hand, are plant pigments that can confer plants with resistance to the adverse effects of drought (Jaleel et al., 2009). Observations in this study suggest that under favourable growth environments, secondary metabolites in sweet potato plants can be stored in the harvestable plant parts as they are not depleted in the protection against drought stress. Thus, they are available in high concentrations for human nutrition and phytonutrition.

The agroecological area (moist coast hinterland) of Umbumbulu (Table 1) was the only location that seemed to concur with reports on carotenoids playing a protective role in photosynthetic tissues of plants growing under water stress conditions (Jaleel et al., 2009). Total carotenoid content increased in Umbumbulu due high $\mathrm{ET}_{\mathrm{o}}$ (Tables 1 and 4) thus demonstrating the unique protection from oxidative damage provided by carotenoids when plants are exposed to water stress. This was, however, not the case in Richards Bay. Not only did the location reduce the phytonutrients, but it further reduced the sugar content of storage roots. The high water deficit and high temperatures (Table 1) in Richards Bay were expected to increase secondary metabolites as the main defence mechanism and as documented in the literature (Podsędek, 2007; Jaleel et al., 2009; Oh et al., 2009). Instead, the concentration levels of these metabolites were higher under favourable environments. Water stress (in Richards Bay) became the main setback in plant's phytonutritional status as they started to experience harsh growth conditions at an early stage, and thus they started to produce secondary metabolites to protect itself at a very early stage of their life cycle. Moreover, instead of storing those secondary metabolites in its organs, these plants became depleted in the continuous struggle to survive harsh growth conditions.

Comparison of the antioxidant activity of storage roots and leaves revealed that sweet potato leaves had a generally high antioxidant activity. A similar observation was reported by Chu et al. (2000). High chlorophyll content in sweet potato leaves and other substances presumably are highly likely to have a health-promoting potential since chlorophyll has also been reported to have many beneficial biological properties to humans (Ferruzzi et al., 2002; Kizhedath \& Suneetha, 2011). Utilization of these leaves as a vegetable could increase food security (mineral nutrient access) and health in the sense that it could add to the number of seasonal leafy vegetables used by rural communities who have limited access to produce markets (Vorster et al., 2007). Storage roots of orange-fleshed varieties showed higher $\beta$-carotene content than the cream-fleshed sweet potatoes, as shown in previous studies (Rautenbach et al., 2010; Laurie \& Van Heerden, 2012; Laurie et al., 2012). The deeper the orange colour, the more the $\beta$-carotene concentration. Sweet potato cultivar A45 contained more than $15 \mathrm{mg} / 100 \mathrm{~g} \beta$-carotene, which can provide $100 \%$ of the recommended daily allowance (RDA) of vitamin A for children between the ages of $4-8$ years (Institute of Medicine of the National Academies, 2006).

\section{Conclusions}

Sugars, $\beta$-carotene, antioxidant activity, and phytonutrients concentration in sweet potato can be increased or reduced by environmental conditions. Favourable environmental conditions for good nutritional quality of sweet potatoes are agroecological areas with mild temperatures. This allows the crop to store its sugars and phytonutrients better than those grown under harsh environments. Contrary to earlier reports on drought stress, this study revealed that a combination of water stress conditions and high temperatures can also reduce phytonutrients concentration in sweet potato harvestable plant parts as the plant is endlessly protecting itself from oxidative stress. This finding suggests that more research is required to investigate sweet potato potential as a drought tolerant crop from the nutritional value perspective.

\section{Acknowledgements}

This study was supported by the University of KwaZulu-Natal in partnership with the Swedish International Development Cooperation Agency (Sida) and the Organization for Women in Science from the Developing World (OWSD).

\section{References}

Agili, S., Nyende, B., Ngamau, K., \& Masinde, P. (2012). Selection, yield, drought tolerance indices of orange-fleshed sweet potato (Ipomoea batatas Lam) hybrid clone. Journal of Nutrition and Food Science, 2(30), 1-8.

Ahmad, F. M., Ashraf, A. S., Ahmad, A. F., Ansari, A. J., \& Siddiquee, M. R. (2011). Nutraceutical market and its regulation. American Journal of Food Technology, 6(5), 342-347. http://dx.doi.org/10.3923/ ajft.2011.342.347.

Ali, N., Falade, K. O., \& Akingbala, J. O. (2012). Effect of cultivar on quality attributes of sweet potato fries and crisps. Food and Nutrition Science, 3(2), 224-232. http://dx.doi.org/10.4236/fns.2012.32033.

Chu, Y. H., Chang, C. L., \& Hsu, H. F. (2000). Flavonoid content of several vegetables and their antioxidant activity. Journal of the Science of Food and Agriculture, 80(5), 561-566. http://dx.doi.org/10.1002/ (SICI)1097-0010(200004)80:5<561::AID-JSFA574>3.0.CO;2-\#.

Ferruzzi, M. G., Failla, M. L., \& Schwartz, S. J. (2002). Sodium copper chlorophyllin: in vitro digestive stability and accumulation by Caco-2 human intestinal cells. Journal of Agricultural and Food Chemistry, 50(7), 2173-2179. http://dx.doi.org/10.1021/jf010869g. PMid:11902975

Food and Agriculture Organization of the United Nations - FAO (1989). The arid forestry: a guide for field technicians. FAO Corporate Document Repository. Retrieved from www.fao.org.

Howitz, W. (1980). Official Methods of Analysis of the Association of Official Analytical Chemists. Washington: Association of Official Analytical Chemists. 
Institute of Medicine of the National Academies - IOM (2006). Dietary reference intake: The essential guide to nutrient requirements. Retrieved from http//www.IOM.edu/.

Islam, S. (2006). Sweet potato (Ipomoea batatas L.) Leaf: Its potential effect on human health and nutrition. Journal of Food Science, 71(2), R13-21. http://dx.doi.org/10.1111/j.1365-2621.2006.tb08912.x.

Jaleel, C. A., Manivannan, P., Wahid, A., Farooq, M., Al-Juburi, H. J., Somasundaram, R., \& Panneerselvam, R. (2009). Drought stress in plants: A review on morphological characteristics and pigment composition. International Journal of Agriculture\& Biology, 11(1), 100-105.

Kizhedath, A., \& Suneetha, V. (2011). Estimation of chlorophyll content in common household medicinal leaves and their utilization to avail health benefits of chlorophyll. Journal of Pharmacy Research, 4(5), 1412-1413.

Kulembeka, H. P., Rugutu, C. K., Kanju, E., Chirimi, B., Rwiza, E., \& Amour, R. (2004). The Agronomic performance and acceptability of orange fleshed sweet potato varieties in the lake zone of Tanzania. African Crop Science Journal, 12(3), 229-240.

Laurie, S. M., \& Magoro, M. D. (2008). Evaluation and release of new sweet potato varieties through farmer participatory selection. African Journal of Agricultural Research, 3(10), 672-676.

Laurie, S. M., \& Van Heerden, S. M. (2012). Consumer acceptability of four products made from beta-carotene-rich sweet potato. African Journal of Food Science, 6(4), 96-103. http://dx.doi.org/10.5897/ AJFS12.014.

Laurie, S. M., Van Jaarsveld, P. J., Faber, M., Philpott, M. F., \& Labuschegne, S. T. (2012). Tans- $\beta$-carotene, selected mineral content and potential nutritional contribution of 12 sweet potato varieties. Journal of Food Composition and Analysis, 27(2), 151-159. http://dx.doi.org/10.1016/j. jfca.2012.05.005.

Lichtenthaler, H. K. (1987). Chlorophylls and carotenoids: Pigment of photosynthetic biomembranes. Methods in Enzymology Journal, 148, 50-382.
Liu, X., Robinson, P. W., Madore, M. A., Witney, G. W., \& Arpaia, M. L. (1999). 'Hass' avocado carbohydrate fluctuations. II. Fruit growth and ripening. American Society for Horticultural Science, 124, 676-681.

Oh, M. M., Trick, H. N., \& Rajashekar, C. B. (2009). Secondary metabolism and antioxidants are involved in environmental adaptation and stress tolerance in lettuce. Journal of Plant Physiology, 166(2), 180191. http://dx.doi.org/10.1016/j.jplph.2008.04.015. PMid:18562042

Podsędek, A. (2007). Natural antioxidants and antioxidant capacity of Brassica vegetables: A review. Lwt-Food Science and Technology, 40(1), 1-11. http://dx.doi.org/10.1016/j.lwt.2005.07.023.

Rautenbach, F., Faber, M., Laurie, S., \& Laurie, R. (2010). Antioxidant capacity and antioxidant content in roots of 4 sweetpotato varieties. Journal of Food Science, 75(5), C400-C405. http://dx.doi.org/10.1111/ j.1750-3841.2010.01631.x. PMid:20629859

Rodriguez-Amaya, D. B., \& Kimura, M. (2004). Harvest Plus handbook for carotenoid analysis - Harvest Plus Technical Monograph 2. Washington: International Food Policy Research Institute.

Smith, B. (2006). The farming handbook. Wageningen: Technical Centre for Agriculture and Rural Cooperation.

Van Jaarsveld, P. J., Faber, M., Tanumihardjo, S. A., Nestel, P., Lombard, C. J., \& Benadé, A. J. S. (2005). $\beta$-carotene-rich orange-fleshed sweet potato improves the vitamin A status of primary school children assessed with the modified-relative-dose-response test. The American Journal of Clinical Nutrition, 81(5), 1080-1087. PMid:15883432.

Vorster, H. J., Jansen van Rensburg, W. S., Van Zijl, J. J. B., \& Venter, S. L. (2007). Re-creating awareness of traditional leafy vegetables in communities. African Journal of Food, Agriculture, Nutrition and Development, 7(4), 1-13.

Wolf, S., Marani, A., \& Rudich, J. (1991). Effect of temperature on carbohydrates metabolism in potato plants. Journal of Experimental Botany, 42(5), 619-625. http://dx.doi.org/10.1093/jxb/42.5.619.

Wong, S. P., Leong, L. P., \& Koh, J. H. W. (2006). Antioxidant activity of aqueous extracts of selected plants. Food Chemistry, 99(4), 775-783. http://dx.doi.org/10.1016/j.foodchem.2005.07.058. 